\title{
The spatial distribution and factors affecting karst cave development in Guizhou Province
}

\author{
ZHOU Zhongfa ${ }^{1,2}$, ZHANG Shaoyun ${ }^{1,2}$, , XIONG Kangning $^{1}$, LI Bo ${ }^{2}$, \\ TIAN Zhonghui $^{1,2}$, CHEN Quan ${ }^{1,2}$, YAN Lihui ${ }^{1,2}$, XIAO Shizhen $^{1}$ \\ 1. School of Karst Science, Guizhou Normal University/State Key Laboratory Incubation Base for Karst \\ Mountain Ecology Environment of Guizhou Province, Guiyang 550001, China; \\ 2. Remote Sensing Center of Guizhou Province, Guiyang 550001, China
}

\begin{abstract}
This research examines the distribution features of 4960 caves across Guizhou Province, while probing the relationship between the caves' spatial patterns and geographic elements. This study is based on hydrogeological and topographic maps of Guizhou. ArcGIS software was used to process the adjacent index, spatial analysis, and coupling analysis of the caves altitude and longitude, as well as the rock properties, lithology, drainage and tectonic division of almost 5000 caves. Based on a point pattern analysis of Guizhou caves, the adjacent index is 0.53 , and the coefficient of variation verified by Tyson polygon reached $72.469 \%$. This figure reflects the clustered distribution pattern of the caves. Across the entire province, caves are divided into four concentrated areas and one weakly affected area. The four concentrated areas are Zunyi-Tongren, Bijie, Qianxinan-Liupanshui, and Guiyang-Anshun-Qinan. The one weakly affected zone is Qiandongnan. The most concentrated among them is the Guiyang-Anshun-Qiannan area, which covers $24.67 \%$ of the total province area, and accounts for $36.63 \%$ of the total province's caves. Cave distribution in Guizhou is characterized as dense in the western part and sparse in the eastern part. Under this study background, the natural elements of formation, including lithology, structure, climate, hydrology, and altitude, and their effects on the distribution, number, and spatial pattern of cave development is analyzed.
\end{abstract}

Keywords: karst caves; geographic information system; spatial pattern; affecting factor; Guizhou

\section{Introduction}

The geologic features and spatial distribution of caves is not random. Rather, they are formed under geographically-specific, long-term natural processes (Han et al., 1995). This study of cave spatial patterns shows how cave development is not the result of a single force, but rather the influence of regional geological conditions, karst types, and geological history

Received: 2016-10-09 Accepted: 2016-12-20

Foundation: National Natural Science Foundation of China, No.41361081; High-level Innovative Talents Cultivation Program of Guizhou Province (Qian Ke He SY [2016]5674); Project of Innovation Program for Postgraduate Education of Guizhou Province, No.[2016]04

Author: Zhou Zhongfa (1969-), Professor and PhD Supervisor, E-mail: fa6897@163.com

Zhang Shaoyun (1992-), MS in Geography, E-mail: zqz6868@sina.com

*Corresponding author: Xiong Kangning (1958-), Professor and PhD Supervisor, E-mail: xiongkn@163.com 
and the interaction between continuous and discontinuous development of karst (Bog li A, 1980; Chen, 1992).

Previous cave studies have focused on the formation and evolution of singular caves (Zhang et al., 2013; Xiong, 1994) using qualitative or semi-quantitative methods (Wang, 2014; Ban, 2011; Chen et al., 2004). These studies apply monitoring data to reveal the impact of environmental changes on ancient caves over time. With the rise of GIS, some researchers have adopted spatial analysis methods to measure the distribution of caves over time and space (Baldini, 2006). However, there has been limited research on the spatial distribution of caves as related to geologic factors at a regional scale. The only research on this subject to date was conducted by Williams P. (2004), which uses polygon theory to analyze karst cave distribution and geomorphic development.

China is the earliest country in the world to record and study karst landforms. The earliest records were found in Jing Dynasty, detailed in the records of Xu Xiake Travels by Xu Hongzhu (1586-1641). Karst landscapes cover a large region in China. The carbonate rocks cover around 1,250,000 $\mathrm{km}^{2}$, distributed mainly across Guangxi, Guizhou, and Yunnan provinces. Guizhou is one of the three most dense karst areas in the world.

The study of karst distribution patterns is based in Guizhou Province. Guizhou is located in the Yunnan-Guizhou Plateau between $103^{\circ} 36^{\prime}-109^{\circ} 35^{\prime} \mathrm{E}$ and $24^{\circ} 37^{\prime}-29^{\circ} 13^{\prime} \mathrm{N}$, and has a subtropical monsoon climate. The exposed carbonate rocks are distributed over $130,000 \mathrm{~km}^{2}$, occupying $61.50 \%$ of the entire area of Guizhou Province. These conditions provide a suitable basis for karst cave development, and explain why Guizhou is an important area for researching karst distribution and cave development. There are a variety of cave types in Guizhou, including hill, underground, water, and interconnected types.

The formation of karsts in Guizhou emerged from a plate group during the Proterozoic to the Quaternary Period, mainly as shallow marine carbonate deposits. The underground karst landscape mainly includes underground rivers, caves, and rifts. The rocks in Guizhou are mainly composed of carbonate rock, which mainly emerged during the Cambrian, Devonian, Carboniferous, Permian and Triassic periods. Specifically, the distribution is as follows: in the Early Paleozoic Period, carbonate rock extended along the northwest, southeast, and southwest parts of the province. In the Paleozoic Period, carbonate was distributed across the whole province, its transition line running from the northwest to southeast of the province. During the Permian and Mesozoic periods, carbonate rock was widely distributed, its transition line running from the northeast to southwest of the province. The direction of these transition lines provided a material base for cave development. Sedimentary belt distribution, depression of change and form, surface drape fault patterns, and characteristics of rock clusters also played an important role in cave formation and distribution. (SPTFG, 1967; Dong, 1997; Xie, 1987). This study of cave distribution in Guizhou seeks to examine and explain the spatial distribution features of cave distribution and its effecting factors using GIS tools such as the neighboring index method, spatial overlay analysis and coupling analysis.

\section{Data and methods}

\subsection{Data source}

Information regarding cave location, strata, rock properties, and altitude was collected from 
Guizhou Province topological map data. Using GIS and RS, the data was overlapped with 1:50,000 topographic maps and 1:200,000 hydrogeological maps (Zhou, 2004) (Figure 1). The coordinate points of 4960 caves were layered on top of these maps and new datasets were created.

\subsection{Methods}

\subsubsection{The adjacent analysis}

The adjacent analysis is one of the point distribution analysis methods, which was first applied to population distribution analysis by ecologist Clark (1954). It has gradually been developed as a mature method of measuring point distribution patterns. The adjacent analysis model was modified by Pinder (1973) and Ebdon (1976) to assess a variety of dataset distribution patterns, such as geologic hazards (Qiu et al., 2014), epidemics (Gan, 2009), residential distribution ( $\mathrm{Li}, 2008)$, settlement distribution (Wu, 2010), urban spatial distribution (Guo, 2015), scenic spots (Qin, 2012), and industrial distribution (Gao, 2013). The modified adjacent analysis model overcomes the terrain restrictions by fitting the study area to a square shape. The closer the study area is to a square box, the greater the accuracy of the adjacent ratio (Wang, 2006). The coordinate points analyzed in this study were based on the coordinate locations of the cave openings.

On the macro level, caves are dotted throughout Guizhou Province. Upon closer examination, there are 3 types of spatial distribution: even, random and clustered. The nearest neighbor index is the most common method for determining the spatial distribution of point features. The spatial distribution characteristics of caves across the province were analyzed using the nearest neighbor index R.

Its equation is (Ruan, 2016; Wang, 2010):

$$
R=\frac{\overline{r_{1}}}{\overline{r_{E}}}=\frac{1}{n} \sum_{i=1}^{n} r_{1}\left(S_{i}\right) *\left(\frac{1}{2 \sqrt{n / A}}\right)
$$

where $\overline{r_{1}}$ is the average value of the adjacent point to the distance $r_{1} \cdot \overline{r_{E}}$ is the average value of the adjacent point to the distance in the random distribution theory, $n$ is the point number, $r_{1}\left(S_{i}\right)$ is the distance between spot $S_{i}$ in the area to the adjacent point, and $A$ is the area. When $R=1$, it means the point distribution is random; when $R>1$, point distribution is even; when $R<1$, point distribution is clustered.

\subsubsection{Thiessen polygons}

There are some different definitions and standards for measuring the spatial distribution of points using the adjacent index (Hu et al., 2015; Zhang, 2005). This study applied the Thiessen polygon method, which is one method for selecting regional discrete sampling points (Zeng, 2011; Liu, 2012; Duan, 2015; Zhu, 2005). The coefficient of variation was defined as the ratio of standard deviation and average of the Voronoi polygon area (Figure 2). It is capable of measuring the variation of relative changes in space. The equation is:

$$
C V=S / M
$$

where $S$ is the standard deviation value of Voronoi polygon area, and $M$ is the average value of Voronoi polygon area. 


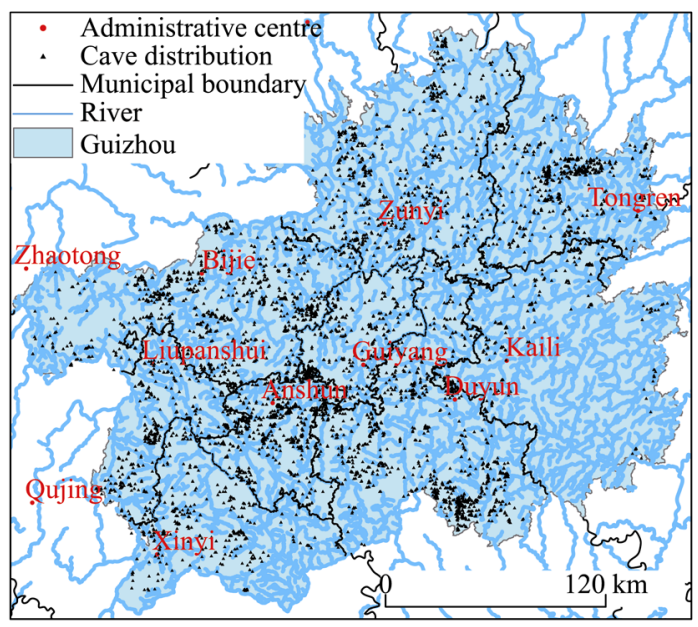

Figure 1 Cave locations in Guizhou Province

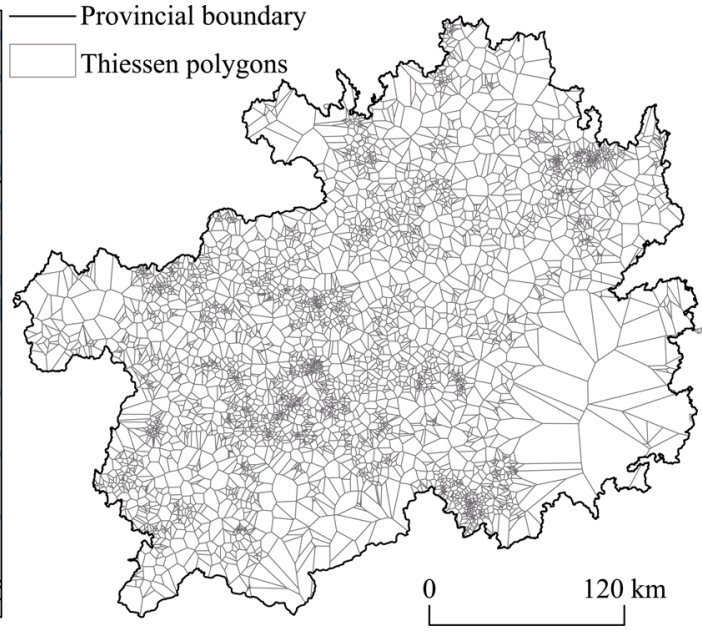

Figure 2 Distribution of Thiessen polygons caves in Guizhou

\section{Results}

\subsection{Analysis of cave spatial pattern}

Analysis of the cave spatial distribution was measured by ArcGIS 10.1 software using the adjacent analysis model in function 1 . Using Guizhou as the study object, where $\overline{r_{1}} \approx 1824 \mathrm{~m}$, and $\overline{r_{E}} \approx 3471 \mathrm{~m}$, the adjacent index is $R \approx 0.53<1$. The analysis indicates that the spatial distribution of caves is highly clustered (Zhang et al., 2011).

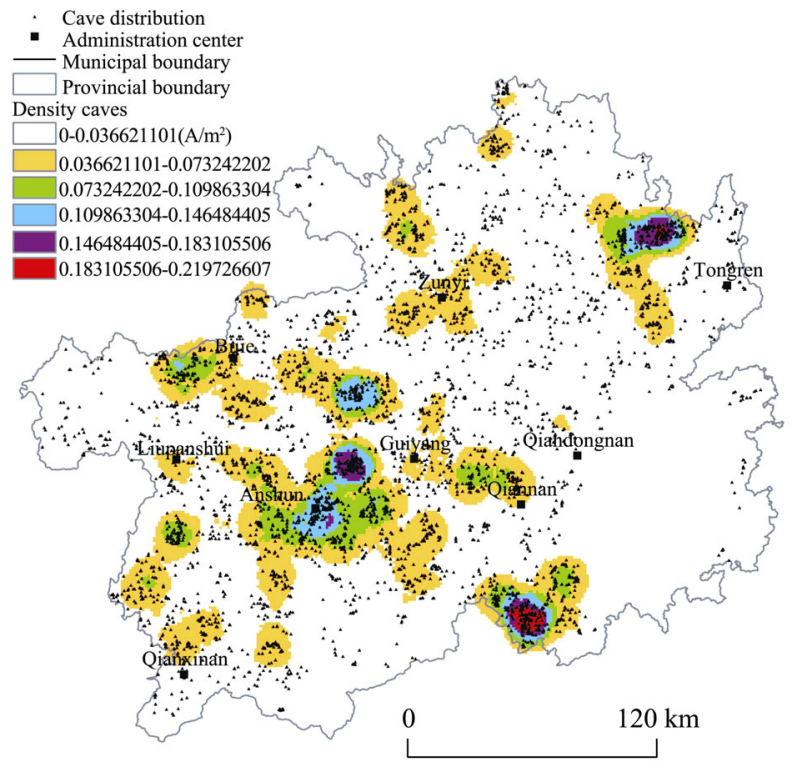

Figure 3 Distribution of cave density in Guizhou
Thiessen polygon maps oriented by cave distribution points across the province indicate that $M \approx 81,000 \mathrm{~m}^{2}$, $S \approx 5,870,000 \mathrm{~m}^{2}$ and the coefficient of variation $C V \approx 72.469 \%$. The study by Duyckaerts (2000) showed that the coefficient of variation equals to $33 \%-64 \%$ when points were distributed randomly; greater than $64 \%$ when points were distributed in clusters; and less than $33 \%$ when points were distributed evenly (Zhu, 1988). The results indicate that the caves in Guizhou are distributed in clusters.

Further analysis of the density distribution of caves (Figure 3) shows that the distribution of caves is patchy. In order to analyze the underlying geologic factors affecting the distri- 
bution pattern of caves, including rock properties, geological layer, hydrology, and geological structure, the 4960 caves across the province were divided into five zones: Zunyi-Tongren, Bijie, Qianxinan-Liupanshui, and Guiyang-Anshun-Qiannan, which exhibited high levels of cluster distribution, and Qiandongnan, which exhibited a low presence of caves (Figure 4).

\subsubsection{Concentrated areas of Zunyi-} Tongren

The Zunyi-Tongren area, which covers $27.69 \%$ of the whole provincial territory, has 1257 caves, making up 25.34\% of

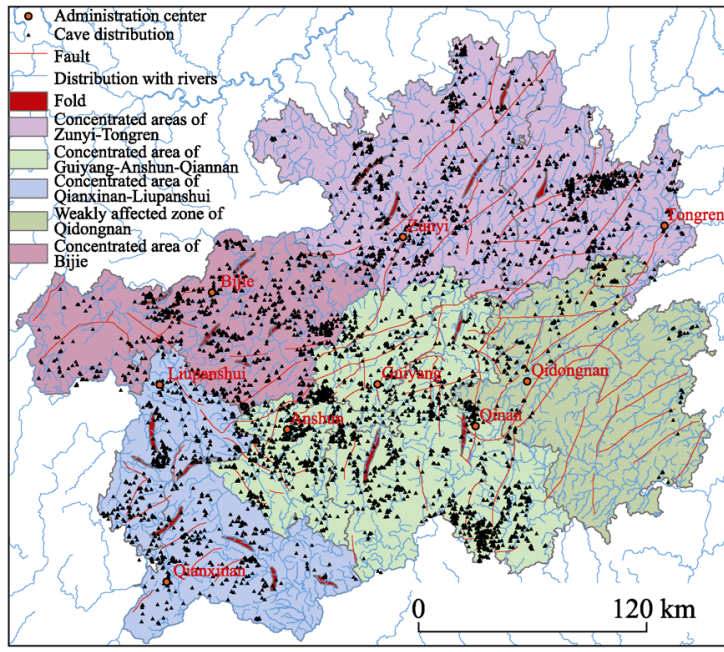

Figure 4 Concentrated cave areas in Guizhou all caves in the province. This area has 19 fault zones and 5 fold zones, which are northeast-trending with ribbon formations. The cave distribution spans from west to east, mainly concentrated in Zunyi and its northwest part, and northwest part in Tongren with fault, fold and water systems. The water systems in this area are primarily outflow river systems. Most caves are located close to the river bank. Cave distribution is strongly affected by the geological layer formation, northeast-trending structure and water systems.

\subsubsection{Concentrated area of Bijie}

The Bijie area, which covers $15.24 \%$ of the whole provincial territory, has 962 caves, making up $19.39 \%$ of all caves in the province. This area has 15 fault zones and 5 fold zones in the northeast, northwest, southeast direction. The caves are mainly distributed in the northeast, east, and west directions and emerged during the Permian Period. The cave distribution span is larger in its central, east, and southeast parts. The average altitude of this area is $1600 \mathrm{~m}$, with large variations. The heads of the Wujiang River, Beipanjiang River and Chishuihe River begin in this area. Most of the caves are a far distance from the river bank. The cave distribution is strongly affected by the geological layer formation in the northeast.

\subsubsection{Concentrated area of Qianxinan-Liupanshui}

The Qianxinan-Liupanshui area, which covers $15.16 \%$ of the whole province, has 692 caves, making up $13.95 \%$ of all caves in the province. This area has 11 fault zones and 7 fold zones in the northeast direction. The caves distribution span is larger in the south and north parts. The caves are concentrated in the dolomite and limestone region in the north-central part, but very few are found in the south-central and eastern parts, being primarily a clastic rock zone. The water system in this area is the upstream of the Yangtze River and Zhujiang River. Most caves are close to a river bank. The cave distribution is strongly affected by the northeast formation and rock properties.

\subsubsection{Concentrated area of Guiyang-Anshun-Qiannan}

The Guiyang-Anshun-Qiannan area, which covers $24.67 \%$ of the whole province, has 1817 caves, making up $36.63 \%$ of all caves in the province. This area has 35 fault zones and 3 
fold zones mainly in the northeast, south, and north directions. It emerged during the Permian and Triassic periods, and lower layer emerged during the Carboniferous Period. The caves are concentrated in areas with carbonate rock, dolomite and limestone. The cave distribution span is larger in the south and north parts, mainly in the northwest part of Anshun and south part of Qiannan. There is a dense network of rivers which run close to the caves. The cave distribution is strongly affected by the northeast, north, and south geological layer formation and rock properties.

\subsubsection{Weakly affected zone of Qiandongnan}

Qiandongnan, which covers $17.22 \%$ of the whole province, has 232 caves, making up $4.68 \%$ of all caves in the province. This area has 22 fault zones and no fold zones. The few caves in this area are distributed mainly in the north and northeast. There is a dense network of rivers. This area has a relatively large amount of fault zones and distribution of clastic rock. The cave distribution is strongly affected by geological layer rock properties.

\section{Spatial distribution of caves and analysis of affecting factors}

In order to research the spatial distribution and influence of geological layer, rock properties, formation, climate, hydrology and altitude on the cave, GIS spatial overlay analysis and coupling analysis are used in this paper.

\subsection{Internal affecting factors analysis}

\subsubsection{Rock properties}

Rock properties are the developing basis of the cave. Soluble rocks are the material condition for karst development and underground cave development (Zhou, 2004). Cave development is not the result of a single force, but rather the influence of regional natural geological conditions, karst types, and geological history. Its development requires soluble rock, which is limited by the distribution, purity and thickness of the carbonate in the rock layer.

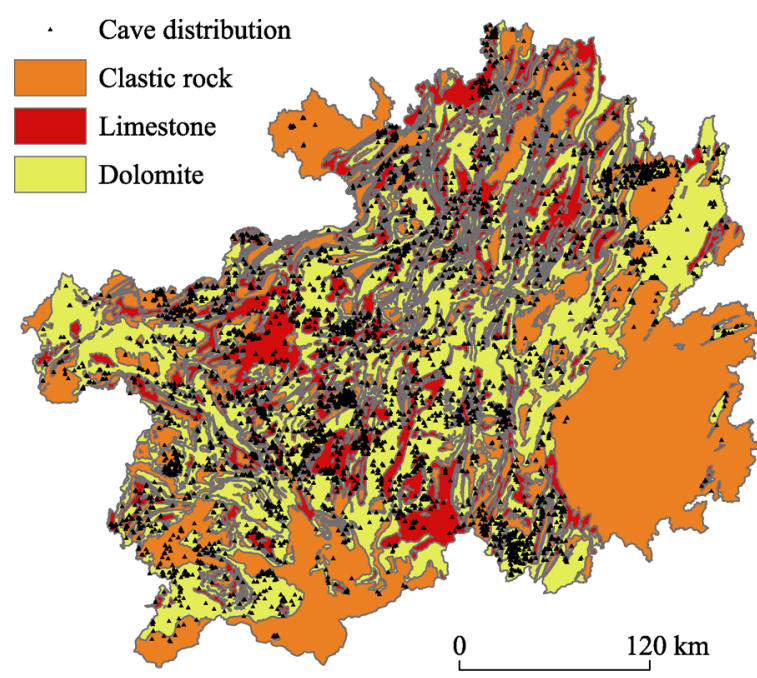

Figure 5 Distribution of caves and rock properties in Guizhou
The carbonate rock in Guizhou mainly consists of pure, thick limestone and dolomite with high calcium and magnesium contents. Its total thickness is $6200 \mathrm{~m}$ to $8500 \mathrm{~m}$, with strong karst development (Dai et al., 2013). Exposed karst formations cover $61.50 \%$ of the whole province. The caves and rock properties map (Figure 5) which shows the locations of caves of clastic rock, limestone and dolomite, was generated in ArcGIS using a 1:200,000 Guizhou rock properties map. The results show that there are 771 clastic rock caves, making up $15.54 \%$ of the total caves in Guizhou, and $38.39 \%$ of the exposed karst area in the province; there are 
3054 dolomite caves, making up $61.57 \%$ of all caves, and $41.23 \%$ of the exposed karst area in the province, mainly concentrated in the Guiyang-Anshun-Qiannan area; there are 1133 limestone caves, making up $28.84 \%$ of all caves, and $20.27 \%$ of the exposed karst area in the province, mainly in the Bijie-Anshun-Qiannan area. The caves are developed mainly in the carbonate rock areas. Clastic rock is a none-soluble rock. Clastic rock caves in the Qiannan area are few.

\subsubsection{Geological layer}

The distribution of geological layers determines the presence or absence of cave development. According to the distribution map of Guizhou caves and geological layers (Figure 6), it is apparent that the geological layers in Guizhou are complete, existing from the Sinian strata to Quaternary strata. There are 14 caves from the Sinian strata, making up $0.28 \%$ of all caves, which are located mainly in the Qiandongnan and Tongren regions; there are 322 caves from the Ordovician strata, making up $6.49 \%$ of all caves, mainly located in the Zunyi region in a ribbon distribution; there are 146 caves of Silurian strata, making up $2.94 \%$ of all caves, mainly in the Zunyi region in a ribbon distribution; there are 158 caves of the Devonian strata, making up 3.18\% of all caves, mainly in the Qiannan region; there are 621 caves of the Carboniferous strata, making up $12.52 \%$ of all caves, mainly in the Bijie and Qiannan regions; there are 1602 caves of the Permian strata, making up 32.29\% of all caves; there are 1330 caves of the Triassic strata, making up $26.81 \%$ of all caves, mainly in west-central, southern, and northern parts of Guizhou; there are 163 caves of the Jurassic strata, making up $3.28 \%$ of all caves, mainly in the Zunyi region in ribbon distribution; there are 18 caves of the Cretaceous strata, making up $0.36 \%$ of all caves, mainly in the west and north parts of Zunyi; there are no caves in the Tertiary strata, mainly in the region of Bijie; and there are 10 caves of the Quaternary strata, making up $0.20 \%$ of all caves, which are scattered throughout the province. According to the above analysis, the quantities of caves in various geological layers are distributed as follows, ranking from the greatest to the least: Permian, Triassic and Carboniferous, Cambrian, Ordovician, Jurassic, Devonian, Silurian, Sinian, Quaternary, Tertiary and Cretaceous.

The carbonate rock layer in Guizhou is over $600 \mathrm{~m}$ thick, which exists among the layers between the Sinan and Triassic strata. The thickness and purity of this massive limestone layer results in the well- developed karst and typical karst landscape. As the example of S-Sn dolomite, the landscape is dominated by karst hills and depressions mainly in the north part of Guizhou with non-significant fenglin. The D-C carbonate rock is well-developed with a large scale underground network of rivers. Its

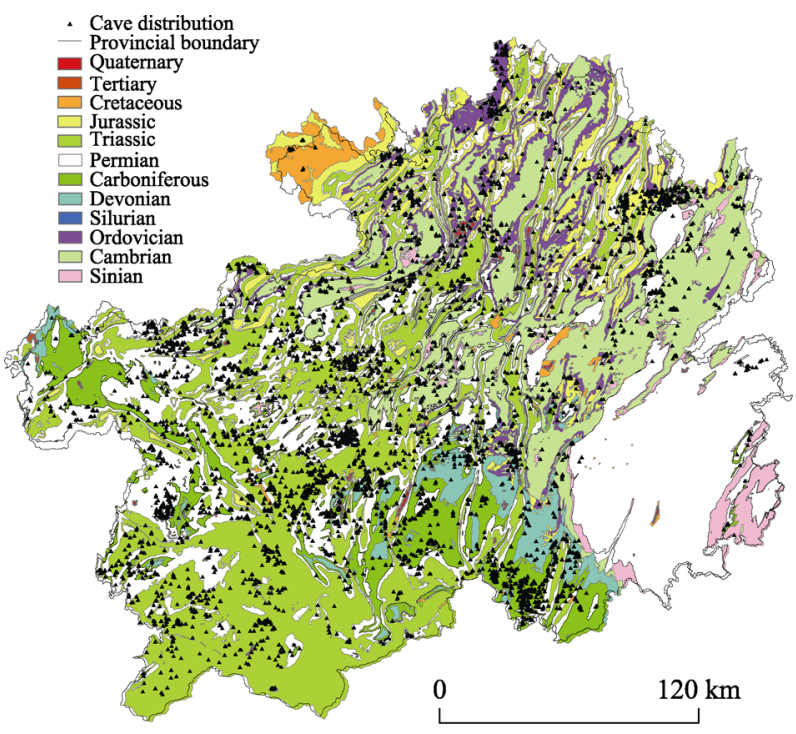

Figure 6 Distribution of caves and geological layers in Guizhou 
rivers. Its landscape is mainly the fenglin. The P-T pure geological layer has various karst landscapes (Stratigraphic paleontology task force in Guizhou, 1967; Dong, 1997; Xie, 1987). The other geological layers are not developed. That is the cause for the rare caves in Qiandongnan, and dense distribution in Guiyang-Anshun- Qiannan.

\subsubsection{Formation}

The formation of folds and faults are the expression of the earth's crust movements, which is a major cause for cave formation and development (Xiong, 1996; Chen, 1994). This research is based on the 1:200000 hydrogeological map of Guizhou Province. The overlay analysis by ArcGIS was carried out on fold and fault layers and buffer zones of 0-500 m, 500-2000 $\mathrm{m}$, and $2-3 \mathrm{~km}$. The overlay analysis map of cave distribution and folds and faults (Figure 7) shows that in the $0-500 \mathrm{~m}$ fold area, there are 66 caves, accounting for $1.33 \%$ of the total number of caves; in the 500-2000 m fold region, there are 56 caves, accounting for $1.13 \%$ of the total number of caves; and in the $2-3 \mathrm{~km}$ fold area, there are 44 caves, which account for $0.89 \%$ of the total number of caves. In the $0-500 \mathrm{~m}$ fault zone, there are 187 caves, which account for $3.77 \%$ of the total number of caves. In the 500-2000 m fault zone, there are 485 caves, accounting for $9.78 \%$ of the total number of caves; and in the $2-3 \mathrm{~km}$ fault zone, there are 358 caves, which account for $7.22 \%$ of the total number of caves. The caves at the intersection of Bijie-Qianxinan-Anshun are obviously affected by fold and fault layers. The affected factors for cave development are divided into various types: same as the axel of fold formation, anticline zone, synclinal area, tectonic fault zone, tectonic fracture zone, crushed fracture zone, open shear fracture zone, joint (fracture) zone, tectonic superposition compound area, fracture of composite zone, fracture zone, and fold compound area (Dai, 2013; Zhang et al., 2000; Zhang, 1986). This indicates that the formation of faults and folds are an important affecting factor for cave development.

The comprehensive analysis of geological layers, rock properties and formations shows

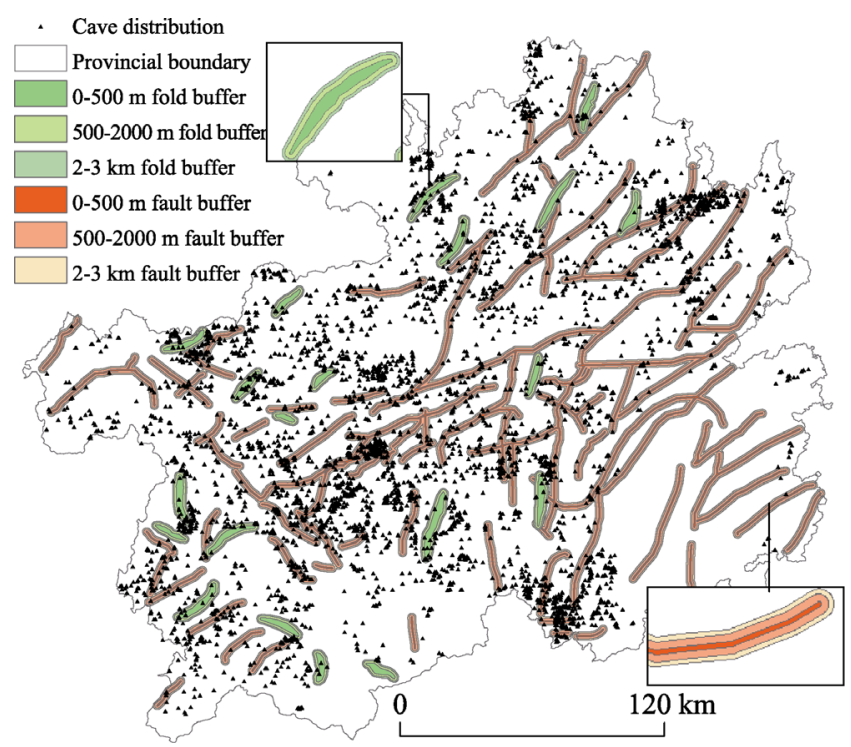

Figure 7 Overlay analysis map of cave distribution and buffer zones of fold and fault layers in Guizhou that caves in Guizhou are evenly distributed among the carbonate rock layers from Sinian to Triassic strata, particularly in the complex geological locations. The distribution of caves is related to rock properties and controlled by the rock formation. The thick limestone has the strongest karst development, while dolomite karst development is mild and clastic rock is very weak. The thick carbonate is highly soluble. Limestone is characterized by a calcite or aragonite content of over $50 \%$. The dolomite content is over $50 \%$. The clastic rock facilitates the flow of water, and determines the 
karst development. That explains the weak cave development in Qiandongnan. Cave development is strictly controlled by the various mineral and mechanical properties of the formation layers. $96.14 \%$ among the total caves in the province are between Sinian and Triassic stratas. The layers in Sinian and Triassic strata provide a vast space and potential development for the carbonate rocks. The carbonate rocks are mainly concentrated in the south-central part of Guizhou. The clastic rocks or un-soluble rocks are mainly in the southeast part of Guizhou. This results in the relatively lower concentration of caves in the southeast part of the province.

\subsection{Analysis of external factors}

\subsubsection{Climate}

Precipitation is one of the key climate conditions that affect cave development. Karst caves are formed by the corrosion and erosion of carbonate by water, and are affected by the amount, physical properties, movement and strength of water (Zhang, 1986; He, 1997). Guizhou is located in the mainland subtropical East Asian monsoon zone. It has a Chinese subtropical plateau monsoon humid climate with plateau and warm climate, and abundant rainfall throughout the year. Annual precipitation is around $1100-1300 \mathrm{~mm}$. The annual temperature is around $14-16^{\circ} \mathrm{C}$. The temperature in July is $22-25^{\circ} \mathrm{C}$. Most of the rainfall goes underground, which, combined with abundant heat and rain, creates good conditions for cave formation. However, it also leads to little surface runoff. Underground runoff and water drainage are good, which sustains processes of corrosion and erosion. This is a major factor affecting cave spatial distribution.

\subsubsection{Hydrology}

Hydrology is one of the major affecting factors for cave formation. Surface and underground rivers overlay on each other. There is a high density of caves along river banks. The river valley is the lowest area of each small watershed, which means the drainage datum of the underground and surface rivers drain in this area. Most of the surface and underground rivers are overlaying on each other, or so called "hidden streams". This explains why caves are commonly exposed above the drainage datum area. The map of cave distribution and river buffer zones is concluded by the overlaying analysis of cave distribution points and river buffer zones across the province, particularly the 0-500 m, 500-2000 m, 2-3 km of rivers buffer zones by ArcGIS based on the 1:200,000 water system distribution map of Guizhou. The results show (Figure $8 \mathrm{a}$ ) that 723 caves $(14.58 \%$ of all caves) are located $0-500 \mathrm{~m}$ from river banks; 1468 caves (29.60\% of all caves are located) are located 500-2000 m from river banks; and 889 (17.92\%) of caves are located $2-3 \mathrm{~km}$ from river banks. It also shows that $62.10 \%$ of all caves are within a $3 \mathrm{~km}$ distance from a river bank. This reveals that most caves are near water-based areas. The caves greater than $3 \mathrm{~km}$ from a river are mainly affected by the tectonic movement and distribution of underground rivers.

Underground rivers refer to underground water channels. They are formed by interactions between rock layers, geological formation, topography, and surface water systems. The presence of an underground river system means that the underground water channel system is combined with underground main streams and sub-streams. Underground rivers are the main form of karst underground water runoff and drainage. This analysis shows that there 
are no cave points within $0-500 \mathrm{~m}$ of an underground river (Figure $8 \mathrm{~b}$ ). It is also shown that there are 219 caves $(4.41 \%$ of total caves) in the 500-2000 m distance; and 206 caves ( $4.15 \%$ of total caves) in the $2-3 \mathrm{~km}$ distance of banks. This indicates that there is a comparatively weak connection between underground cave water and the exposed caves at the surface. However, underground rivers are the main source for cave formation and development. Surface and underground water resources are abundant in the study area, which is a driving cause of cave development.
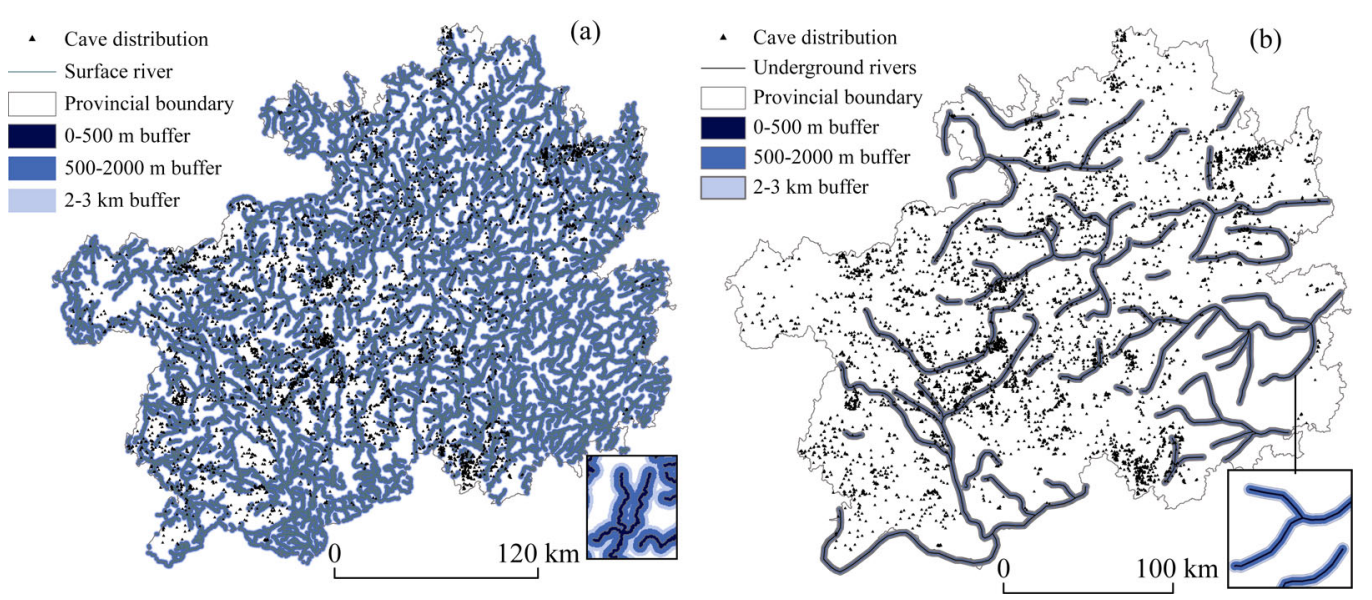

Figure 8 The overlay analysis map of cave distribution and surface (a) and underground (b) river buffer zones in Guizhou

\subsubsection{Altitude}

Altitude is one of the factors affecting the longitudinal layout of caves. It is hard to process visualization overlay analysis of DEM data for the numerous data of the whole province. The elevation height results are summarized by the SPSS19 in Figure 9. It shows approximately three elevation height ranges for most caves: (1) $36.96 \%$ caves are at an altitude between $1100 \mathrm{~m}$ and $1500 \mathrm{~m}$; (2) $20.56 \%$ between $900 \mathrm{~m}$ and $1100 \mathrm{~m}$; (3) $12.56 \%$ caves be-

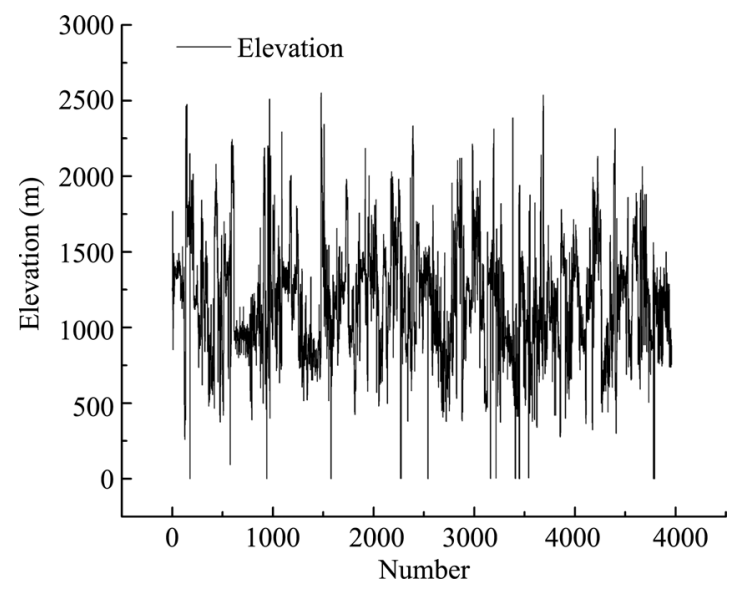

Figure 9 Altitude distribution cave map in Guizhou tween $700 \mathrm{~m}$ and $900 \mathrm{~m}$.

Generally, caves are vertically distributed. Distribution varies depending on terrain formation, rock properties, geological structure, particularly the karst cone landscape (Xiong, 1992, 1996). The extensive development of karsts led to the distribution of caves at different elevations. Some $70.08 \%$ of the caves are concentrated at an altitude of 700-1500 m, which are affected by rock properties and cone karst landscapes with wide middle mountains and thick limestone rock layers suitable for cave development. Caves 
above $1500 \mathrm{~m}$ are affected by rock properties and cone karst landscapes, which result in fewer cave formations. Caves under $700 \mathrm{~m}$, of which there are few, are mostly in the depression and river valley area. They are affected by the vertical distribution of caves.

The abundant heat and rainfall of Guizhou provides sufficient water conditions for karst formation according to the comprehensive external factors like climate, hydrology, and altitude, etc. Most of the rainfall penetrates into the underground, which creates favorable conditions for cave formation. Based on this, caves in Guizhou should be distributed across the whole territory. However, Qiandongnan only has 232 caves, or $4.68 \%$ of the total number of caves, even though it covers $17.22 \%$ of the whole province. This reveals that cave development is mainly affected by internal factors, rather than external factors like climate, hydrology, and altitude. Generally, the rock property is the primary affecting factor, and climate, hydrology and altitude are secondary. Qiandongnan, which is characterized by a wide distribution of clastic rock, has a lower cave density relative to other areas. Caves are mainly distributed in the carbonate rock area and close to rivers. The cave distribution is affected by cave altitude and hydrological factors. Most of the caves are distributed between $700 \mathrm{~m}$ and $1500 \mathrm{~m}$, with the cave opening facing the river area. This indicates that these points were the lowest drainage datum during some geologic period.

\subsection{Sub-spatial pattern affected by the internal and external factors}

Guizhou is located in a subtropical monsoon zone with abundant rainfall and heat. Most of the rainfall penetrates into the underground, which creates good conditions for underground cave formation. There is a close relationship between cave formation, geological structure, rock properties, lithofacies, water system evolution, neotectonic movement and landscape development. Rock properties (specifically, soluble rock) is the material foundation for karst development and underground river development. The formation, development and distribution of the underground rivers are restricted by the distribution, purity, and thickness of soluble rocks. The carbonate rock layer in Guizhou is from Sinian to Triassic strata with a thickness of $600 \mathrm{~m}$. A typical karst landscape is characterized by thick and pure limestone and strongly developed karsts. Geological formation is the leading factor for karst development. Karst development is restricted by various formation parts and mechanical properties in various formation layers. The dense folds make carbonate rock into a ribbon extension. That is the reason that the karst development is in a ribbon distribution, with its axial running the same direction as the karst channel and rock layer.

The large-scale intermittent uplift happened from east to west during the Neocene and early Quaternary Period. The strong uplift happened during the end of Pliocene and early Pleistocene periods. Neotectonic movement has occurred frequently since the Quaternary Period, and particularly since the middle Pleistocene Period, which produced different amounts of fault and uplift movements, thereby changing the original terrain. This has a huge effect on the caves vertical distribution at various altitudes. When the earth's crust is stable, channel development is horizontal. When the earth's crust is in uplifted, the channel development is sideways or vertical with underground shafts. When the earth's crust is back to the stable status, the channel development is back in the horizontal direction. This causes the transverse and longitudinal distribution of caves.

As detailed above, the divided affected zones of cave spatial distribution are mainly by 
point density function, rock properties, geological layers, hydrology, formation, climate, and altitude, as well as consideration of the provincial administrative division of Guizhou. According to the concentrated area of Zunyi-Tongren, the geological layers are mainly the layers of Cambrian and Triassic strata. The caves in this area are mainly formed from dolomite and limestone rocks. According to the concentrated area of Bijie, the geological layers are mainly the layers of Permian, Triassic and Carboniferous strata. The carbonate rock layers in Guizhou exist in Sinian to Triassic strata. Its caves mainly developed from limestone and dolomite rocks. Its caves are distributed across Permian limestone. The layer in the concentrated area of Qianxinan-Liupanshui is mainly in the Cambrian and Permian strata. Its caves mainly developed from limestone and dolomite rocks. Its formation is in the southwest and northeast direction. The layer in the concentrated area of Guiyang-Anshun-Qiannan is mainly in Permian, Triassic and Carboniferous strata. Its caves mainly developed from dolomite and limestone rocks. The cave distribution follows the geological layer and formation concentration. The layer in the weak affected area of Qiandongnan is mainly of the Permian strata. Its caves mainly developed in the Carboniferous and Silurian strata. The rock properties in this area are mainly clastic rock. The rock properties in the Carboniferous and Silurian layers are mainly carbonate. The cave distribution follows the formation lithology concentration.

\section{Conclusions}

(1) This study reveals that the cave distribution in Guizhou is formed in an obvious ribbon pattern, which is distributed more densely in the west part and more sparsely in the east part of Guizhou. The cave distribution is not random but a result from geologic factors. The 4960 caves across the province are divided into four concentrated areas (Zunyi-Tongren, Bijie, Qianxinan-Liupanshui, and Guiyang-Anshun-Qiannan), and one weakly affected area (Qiandongnan). This study has conducted a spatial analysis of factors affecting cave formation, including location, rock properties, geological layer, and hydrology.

(2) The caves in Guizhou are mostly distributed in carbonate rock layer, fault and fold, and water system zones. Cave distribution is affected by geological layers, rock properties, formation and hydrology, etc. For example, the concentrated area of Guiyang-AnshunQiannan is mainly in Permian, Triassic and Carboniferous strata, which has 35 fault and 3 fold zones. Carbonate, dolomite and limestone rocks are concentrated in this area. The density of rivers in this area is high. The caves in this area are $36.63 \%$ of all caves, and $24.67 \%$ of the provincial territory.

(3) Distribution analysis was conducted for 4960 caves in Guizhou using the adjacent analysis and Thiessen polygons methods. The results of this analysis indicate that the adjacent index is 0.53 , which means the caves in Guizhou tend to be concentrated in cluster formations. The coefficient of variation verified by Thiessen polygons is $72.469 \%$, which verifies this conclusion. This research provides geologic criteria for seeking new caves and offers an improved scientific mechanism for analyzing the spatial distribution of caves.

\section{References}

Baldini J U L, Baldini L M, McDermott F et al., 2006. Carbon dioxide sources, sinks, and spatial variability in 
shallow temperate zone caves: Evidence from Ballynamintra Cave, Ireland. Journal of Cave and Karst Studies, 68(1): 4-11.

Ban F M, Cai B G, 2011. Research on seasonal variations of the air's main environmental factors in the Shihua Cave, Beijing. Carsologica Sinica, 30(2): 132-137. (in Chinese)

Bögli A, 1980. Karst Hydrology and Physical Speleology. Berlin: Springer-Verlag, 1-248.

Cao W F, 2001. Water resources involving karst large spring and underground river in Guizhou Province. Guizhou Geology, 18(1): 37-43. (in Chinese)

Chen C M, 1992. Karst caves in diwas (geo-depressions), China. Geological Review, 38(3): 215-223. (in Chinese)

Chen C M, 1994. Karst cave development and mineral deposit feature in Hunan boundary. Geotectonica ct Mctallogcnia, 18(2): 183-190. (in Chinese)

Chen W H, Deng Y D, Han D S et al., 2004. The environment of the reed flute cave and the great cave in Guilin. Carsologica Sinica, 23(2): 29-35. (in Chinese)

Clark P J, 1954. Distance to nearest neighbour as a measure of spatial relationships in populations. Ecology, 35 : 445-453.

Dai C G, Wang M, Chen J S et al., 2013. Tectonic movement characteristic and its geological significance of Guizhou. Guizhou Geology, 30(2): 119-124. (in Chinese)

Dong W P, 1997. Stratigraphy (Lithostratic) of Guizhou Province (Multiple Classification and Correlation of the Stratigraphy of China (52)). Beijing: China University of Geosciences Press. (in Chinese)

Duan D Z, Du D B, Liu C L, 2015. Spatial-temporal evolution mode of urban innovation spatial structure: A case study of Shanghai and Beijing. Acta Geographica Sinica, 70(12): 1911-1925. (in Chinese)

Duyckaerts C, Godefroy G, 2000. Voronoi tessellation to study the numerical density and the spatial distribution of neurons. Journal of Chemical Neuroanatomy, 20: 83-92.

Ebdon D, 1976. On the underestimation inherent in the commonly used formulae. Area, (8): 165-169.

Gao C, Liu Q Y, 2013. Tourism cluster-based study on the development of scenic areas: A case of Xuanwu Lake, Nanjing. Tourism Forum, 6(3): 75-80. (in Chinese)

Gao J, Wang Z Q, Shao Q et al., 2009. Ripley's L index and the nearest neighbor 'hot spots' analysis in epidemiological spots map analysis. Journal of Shandong University (Health Sciences), 47(3): 89-93, 97. (in Chinese)

Guo J, Lv Y Q, Shen T Y, 2015. Urban spatial structure based on point pattern analysis: Taking Beijing metropolitan area as a case. Economic Geography, 35(8): 68-74, 97. (in Chinese)

Han J, Li T C, Mao Dongli et al., 1995. Basic researches on karst caves in Jilin Province. Journal of Northeast Normal University (Natural Science Edition), 3: 113-117. (in Chinese)

He Y b, Zou C J, 1997. On the depth of karst cave development. Carsologica Sinica, 16(2): 72-80. (in Chinese)

Hu M J, Hou G L, Zhou N X et al., 2015. Spatial distribution patterns and multi-scale features of the Lushan forest landscape. Acta Ecologica Sinica, 35(16): 5294-5305. (in Chinese)

Li X L, Liu Z B, Zhao J, 2008. Space distribution type of residential area in Shiyang river basin. Journal of Inner Mongolia Agricultural University (Natural Science Edition), 29(4): 97-101. (in Chinese)

Liu X F, Zhang Z, Shuai J B et al., 2012. Effect of chilling injury on rice yield in Heilongjiang Province. Acta Geographica Sinica, 67(9): 1223-1232. (in Chinese)

Pinder D A, 1973. Nearest neighour analysis of linear point patterns. Tijdschr Econ Soc Geography, 64: 160-163.

Qin Z X, Zhang W, 2012. Analysis for tourism spatial organization in Ordos. Modern Urban Research, (12): 100-104. (in Chinese)

Qiu H J, Cao M M, Liu W et al., 2014. Research on the spatial point pattern of geo-hazard: A case of Ningqiang county. Journal of Arid Land Resources and Environment, 28(3): 107-111. (in Chinese)

Ruan H B, Wang N A, Niu Z M et al., 2016. Spatial pattern of ancient city sites and its driving forces in Mu Us Sandy Land during Han Dynasty. Acta Geographica Sinica, 71(5): 873-882. (in Chinese)

Stratigraphic Paleontology Task Force in Guizhou (SPTFG), 1977. Regional Strata Table (Archies of Guizhou Province) of Southwest China. Beijing: Geological Publishing House. (in Chinese)

Wang D G, Lu L, Chen T et al., 2006. Spatial organization analysis of tourism region in Hulun Buir-Aershan. 
Geographical Research, 25(1): 161-170. (in Chinese)

Wang J F, Liao Y L, liu X, 2010. Spatial Data Analysis Tutorial. Beijing: Science Press, 76-77. (in Chinese)

Wang X X, 2014. The Character of Carbon Variation and Source of $\mathrm{CO}_{2}$ in Xueyu cave[D]. Chongqing: Southwest University. (in Chinese)

Williams P, 2004. Polygonal karst and palaeokarst of the King Country, North Island, New Zealand. Zeitschrift für Geomorphologie, 136(Suppl.): 45-67.

$\mathrm{Wu} \mathrm{H} \mathrm{H,} \mathrm{2010.} \mathrm{The} \mathrm{research} \mathrm{on} \mathrm{spatial} \mathrm{patterns} \mathrm{of} \mathrm{the} \mathrm{distribution} \mathrm{of} \mathrm{prehistoric} \mathrm{settlements} \mathrm{in} \mathrm{Central} \mathrm{Plains} \mathrm{[D].}$ Zhengzhou: Henan University of Technology. (in Chinese)

Xie J B, Wang K X, Han B Z, 1987. Regional Geology of Guizhou Province. Beijing: Geological Publishing House. (In Chinese)

Xiong K N, 1992. Morphometry and evolution of fenglin karst in the Shuicheng area, western Guizhou, China. Z. Geomorph. 36(2): 227-248. (in Chinese)

Xiong K N, 1996. Development of cone karst in response to neotectonism in Guizhou. Guizhou Geology, 13(2): 181-186. (in Chinese)

Xiong K N, Zhu W X, 1994. Karst geomorphology and speleogenesis of the Zhijin cave area. Carsologica Sinica, 13(3): 281-292. (in Chinese)

Zeng H W, Li L J, 2011. Accuracy validation of TRMM 3B43 data in Lancang river basin. Acta Geographica Sinica, 66(7): 994-1004. (in Chinese)

Zhang H, Wang X S, Yu R L, 2005. Voronoi diagram to study the spatial distribution pattern of point sets. Journal of Central China Normal University (Nature Science), 39(3): 422-426. (in Chinese)

Zhang M L, Lin Y S, Ran J C et al., 2000. The characteristics of karst caves development in Libo, Guizhou. Carsologica Sinica, 19(1): 15-22. (in Chinese)

Zhang X M, Wang J, Zhen Q H et al., 2013. Geomorphic features, sedimentary characteristics and their influencing factors of Kongshan Baiyun cave in Lincheng, Hebei Province. Journal of Palaeogeography, 15(1): 49-58. (in Chinese)

Zhang Y G, 1986. The regional difference of karst cave development in China. Geographical Research, 5(4): 36-46.

Zhang Y P, Wu J S, Huang X L et al., 2011. A study on the tourism spatial structure over the west coast of the Taiwan Strait economic zone. Resources Science, 33(9): 1799-1805. (in Chinese)

Zhou Z F, 2004. Design and application of karst cave information system of Guizhou [D]. Guiyang: Guizhou Normal University. (in Chinese)

Zhu D H, Tan H R, 1988. In genetic research of cave types and karst caves. Tourism Tribune, (S1): 41-46. (in Chinese)

Zhu Q A, Zhang W C, Zhao D Z et al., 2005. Topography-based spatial daily Precipitation interpolation by means of PRISM and Thiessen polygon analysis. Scientia Geographica Sinica, 25(2): 233-238. (in Chinese) 